\title{
Hands Across The Atlantic?
}

Terry Young (E-mail: tyoung@ pepperdine.edu), Pepperdine University, USA

Peggy Crawford (E-mail: pcrawfor@pepperdine.edu), Pepperdine University, USA

\begin{abstract}
The war in Iraq created a division between the United States and some members of the European Union. The war also split the EU, with France and Germany leading the anti-war camp and Britain, Italy, Portugal, and Spain supporting Washington. With organized warfare over, the United States has shifted its attention from the military campaign to the installation of a legitimate and stable government in Iraq. However, the administration of post-war Iraq has caused the division between the US and Europe to widen.
\end{abstract}

The multilateralists, France and Germany, are demanding a central role for the UN in rebuilding Iraq. France, in particular, believes that the task should be left to the UN alone. They suggest this would help legitimize what they consider to be an illegal war. On the other hand, the US, which accepted a great burden with the pre-emptive attack on Iraq, wants the UN to have a "vital" but limited role in post-war Iraq. The US believes that the UN needs serious repair before any responsibilities can be handed to it.

This study examines the economic, political, and security implications of the division between these old allies. The relationship between the US and EU is based on years of cooperation. Both sides know that they must mend fences sooner rather than later. We contend that pragmatism will triumph over geo-politics.

\section{Introduction}

The war in Iraq created a division (or highlighted an existing one) between the United States and some members of the European Union. At the same time, the war split the EU, with France and Germany leading the antiwar camp and Britain, Italy, Portugal, and Spain supporting Washington. More importantly, the Iraq crisis may have impacted the future relationship between the Atlantic allies. This study examines the political, economic, and security implications of the current divisions and speculates on the future course of events.

\section{Déjà Vu - All Over Again!}

History has a way of repeating itself, but often we do not learn from the past. The Suez crisis of 1956 provides many parallels to today's events. During this crisis, the French and British governments grew impatient with the United Nations' inability to agree on a resolution. They launched a military attack with the goal of replacing the regime of the Egyptian dictator, Jamal Abdul Nasser. The US was concerned about the legality and the international impact of the war without a wider mandate. The Franco-British Suez intervention failed because the US applied economic pressure to the British pound forcing the British government to call an immediate ceasefire.

France and Britain learned different lessons from this event. After the British government recovered from its anger over the Americans" "betrayal", it concluded that British foreign policy should always be carefully aligned with US global objectives. On the other hand, the French prime minister was in the midst of a meeting with the German chancellor when the ceasefire was announced. The two countries denounced the British and the Americans as unreliable and determined that it was time to build a united Europe. 
Views and policies seem to still be guided by this event. Britain believes that Europe and the US can mold the world together; France thinks Europe must balance American power. (The Economist, March 22, 2003, p. 47)

\section{Political Implications}

Events in the UN Security Council prior to military action, the war itself, and now the reconstruction of Iraq have changed the political environment. Anti-Americanism is displayed in cities and countries around the world. Acts of terrorism have increased and the fear of another major attack on US soil has grown. The relationships between the allies and the role of international institutions have been impacted - possibly forever. Below are some of the events, policies, and perceptions that are currently influencing the political climate.

\subsection{Divided Europe}

The Iraq crisis exposed a European Union with fragmented foreign policies among its members. During the crisis, British Prime Minister Tony Blair warned about the need to maintain a transatlantic unity while French President Jacques Chirac insisted on a multi-polar world, i.e. EU must be able to stand up against American power. Both views have supporters in the rest of Europe. Spain, Portugal, Italy, and most of the smaller countries in Central and Eastern Europe adhere to the British view. France, Germany, and their neighbors Belgium, the Netherlands and Luxembourg advocate independence from US policy. Some of the strongest supporters of the French/German position are not EU members, but Russia, many Arab nations and much of the Islamic world. The French strategic alliance with Russia has caused some concern especially for the new EU members from Eastern Europe whose memories of 50 years of Soviet dominance are still fresh. (The New York Times, May 30, 2003, p. A29)

With victory at hand, the United States has shifted its attention from the military campaign to the installation of a legitimate, stable government in Iraq. However, the administration of post-war Iraq has caused the divisions between the US and Europe, and within Europe to widen. The fight continues after the end of the organized conflict as the French/German/Russian alliance vies for a role for the United Nations - and themselves in post-war Iraq.

\subsection{Divide And Rule}

The US has supported unity for Europe since the establishment of the Committee for a Unified Europe in 1948. Americans saw a unified Europe as a way to prevent the continent from lapsing into another war and as a counter-balance to the Soviet bloc during the Cold War.

Just last year, President George W. Bush said in Berlin "when Europe grows in unity, Europe and America grow in security." However, American policy seems to be making a historic shift - from unification to dissection of Europe. The US security doctrine appears to be explicitly aimed at preserving the hegemony. Surprised Europeans interpret this as a move by the Bush administration towards a policy of "divide and rule." They perceive that the US is trying to "cherry pick" among European allies and "gloat over the divergence in Europe". (The Economist, April 26, 2003, p. 51)

There have been many attempts to unify Europe, mainly by force, but none as successful as the European Union. It has taken almost fifty years, and many compromises, for Europe to reach this point. The question is can (and should) the US solve the world's problems on its own or would a strong, unified Europe provide the extra hand needed to successfully shape the new world order. The answer to that question should determine US/European policy. 


\subsection{Paralysis Of The Multilateral Institutions}

The role and status of the United Nations is being challenged. The US is still angry over its inability to secure a resolution from the Security Council in support of military action in Iraq. Secretary of State Colin Powell, who many believe urged President Bush to work through the UN, felt betrayed by the refusal of the French and Russian governments to support US policy and the inability of the Security Council to agree on the proposed resolutions.

The role of the UN in post-war Iraq is now a bone of contention. France and Germany are demanding a central role for the UN in rebuilding Iraq. They believe that UN leadership will not only legitimize the illegal US action, but also protect their long-standing economic ties with Iraq. However, the unilateral Bush wants a "vital" but limited UN role, and has implemented a Pentagon-led program to manage the transition to a new Iraqi government. Americans are in charge of oil and other key positions in the interim. Britain, on the other hand, has taken a different tack from the US, has stated the importance of a UN role, and is trying to develop a compromise. However, their efforts to date have had limited impact.

The Bush administration did ask for UN support on another issue. With the war over and Saddam's regime toppled, the US asked the UN to lift its sanctions on Iraq. Many felt that without the lifting of sanctions it would be legally possible but highly controversial for the US to rebuild Iraq. (Business Week, May 5, 2003) After negotiation and compromise, the Security Council voted, 14-0, on May 22, 2003 to lift the sanctions. Syria, the only Arab country on the Security Council, did not cast its vote as the government was still weighing its decision when the vote was taken. France, which had threatened to abstain, cast a positive vote after the resolution was revised to give the UN a greater oversight role. (Los Angeles Times, May 23, 2003, p. 1)

Does the UN have a legitimate role as arbiter in global conflicts? In reality, the institutions and procedures of global multilateralism have rarely worked well to solve problems. The UN was almost paralyzed during the Cold War because of the veto power of the five permanent members of the Security Council. Since the end of the Cold War, its record is not much better. It has been unable to act in Africa to stop genocide and ethnic cleaning, and has had some success in the Balkans only after years of debate and loss of life. It appears to take less time to overthrow a regime than to pass a $\mathrm{UN}$ resolution.

Is multilateralism necessary in the world today? We know that multilateralism that leads to paralysis is not inherently moral, any more than unilateralism in service to good is necessarily immoral. But, today in our small, interconnected world, one nation cannot survive alone nor can one nation dictate terms to the rest of the world. Unilateralism is not the answer and the only way to counter unilateralism is to make multilateralism work. If the multilateral machinery is in serious need of repair, fix it. The UN must be transformed if it is to provide the venue for multilateral debate and action, and this can only be accomplished with the cooperation of member nations. (Business Week, April 23, 2003, p. 42)

Post-war Iraq can be the place to start rebuilding the framework of multilateralism. Europe must acknowledge that preemption, even without the imprimatur of the UN, can be a legitimate foreign policy. The US must accept that a UN presence may help create a democratic Iraq and reduce anti-Americanism. These actions would help to establish the UN as a legitimate multilateral institution. By voting to lift sanctions, the members of the Security Council have taken a step toward reconciliation and cooperation.

\subsection{The Arrogant Empire}

The Bush administration's decision to unilaterally reconstruct Iraq has created several problems. Among these is the image projected by this action of the US as an imperial power. Many Europeans and most Arabs are suspicious of the reason the US "liberated" Iraq. "No war for oil" became the rallying slogan as anti-Americanism grew around the globe. Although the swift victory silenced some of the criticism, the continued US "occupation" of Iraq and the inability to find "weapons of mass destruction" has started the grumbles again. (Los Angeles Times, 
May 31, 2003, p. 1) US and coalition citizens and interests have become targets of suicide bombers and other terrorist actions. The May 2003 bombings in Riyahd and Casablanca demonstrate the risk. Would global peacekeepers authorized by the UN reduce the resistance to American occupiers in a Muslim country? It is an option that President Bush may want to explore.

\section{Economic Impact}

The world economy has operated under the shadow of uncertainty for the past few years. The technology bust of March 2000 was followed by 9/11, the war on terrorism, accounting scandals, and the SARS epidemic. The US economy has not fully recovered from the recent recession and Germany, the economic giant of Europe, faces little or no economic growth. The chilly relationship and increasing tensions between the two continents continue to dampen consumer confidence and business sentiments. Below are listed some of the economic ramifications of the continuing division.

\subsection{Tit For Tat}

The reconstruction of Iraq offers the possibility of large economic dividends to the private sector. However, most contracts have been awarded to American firms and many foreign companies have been locked out or at least threatened with exclusion. For example, Sodexho, the French catering group, saw their value drop 7.43 percent in March 2003 when the US Senate voted to cancel its $\$ 881$ million contract to provide food for US Marines. The contract was approved only after Sodexho demonstrated that 40 percent of its 314,000 workers are Americans. (The London Times, April 17, 2003, p. 20)

If incidents such as the one Sodexho faced continue, retaliation by other countries may occur. Given the number of American companies operating in Europe and the amount of money involved in their projects, this could be have tremendous impact on some American firms and the US economy as a whole.

The Bechtel Group, Inc. was awarded a $\$ 680$ million contract in April 2003 by the US government to be spent over the next 18 months on the reconstruction of Iraq. The San Francisco firm intends to do only a small amount of the work itself and to act as supervisor for the rest. More than 7,200 firms from 89 countries have registered for the additional projects -56 percent from the US. Bechtel has warned that the work will be difficult and dangerous and not particularly rewarding financially. Most the contracts that have been rewarded thus far are for less than $\$ 500,000$ on average. In addition, priority is being given to Iraqi companies. However, this one contract illustrates the magnitude of the reconstruction effort, the global interest in participating, and the opportunity mend fences. (Los Angeles Times, June 23, 2003, p. C1)

\subsection{Freedom Fries}

The global operations of Corporate America and Europe Inc depend on a multilateral world. Boycotting each other goods will not only negatively affect profitability and shareholders' value, but it will limit the choice of goods available to consumers. The "unofficial" American boycott of French goods has impacted sales of some products particularly wine and food. A New York based French wine merchant said sales fell 10 percent during the month of March 2003. Ernest-Antoine Selliere, head of the French employers' federation admitted that the boycott could inflict damage on the French economy and stated that US citizens should "vent their anger by writing the French Embassy while sipping a glass of Bordeaux or Burgundy as they do". (The London Times, April 17, 2003, p. 20)

The US is a major importer of French products accounting for 7.8 percent of French exports or $\$ 26$ billion in 2002. American consumers are addicted to French products from perfume to wine to airplanes. During a period when the French economy is weak and American preference for French goods is high, should the French government marginalize itself in the US market? (Ibid, p. 20) 


\subsection{Trade}

The latest round of world trade negotiations, the Doha Round, took place in November 2001. This round established a deadline of the end of 2002 to obtain an agreement on the compulsory licensing of patented drugs and on access to cheap generic drugs for poor countries. Although the Doha Round embraced a broad agenda of trade topics, it stalled over the issue of agricultural subsidies.

Developing nations, which felt short-changed in the Uruguay Round, looked to Doha to provide freer trade in farm goods. They hoped that more open markets would increase their ability to compete with cheap (subsidized) EU farm products. The developing nations are reluctant to go through another round of trade negotiations until progress is made on agricultural reform. If the impasse on agriculture continues, trade agreement may not succeed and the entire system may fall into disrepute. (The Economist, March 29, 2003, p. 63)

To complicate matters, President Bush signed a bill last year supporting a domestic farm subsidy program to help American farmers compete with the enormous subsidies the EU lavishes on its farmers. The US claims it is ready to dismantle subsidies if the playing field is level. However, the EU rejects the idea of abolishing export subsidies and it has not proposed any serious reform on the common agricultural policy (CAP). Instead, the French (a major benefactors of farm subsidies) and Germans have agreed to keep CAP spending unchanged until 2013. (The Economist, January 11, 2003)

The failure of the Doha Round has serious implications since bilateral disputes have been put on hold. The argument over American steel tariffs, for example, could worsen. The EU has already issued an ultimatum with a September deadline for the US to repeal "foreign sales corporations", tax-avoidance vehicles that act as export subsidies, and announced that it would impose trade sanctions worth $\$ 4$ billion. A week after the announcement, the US challenged the EU's ban on imports of genetically modified food at the World Trade Organization. The continued US-EU tensions may set back free trade talks and lead to tougher negotiating stances. Frustration seems to be spilling over into other areas of negotiation and both sides appear to be less willing to compromise. (The Economist, May 17, 2003, p. 63)

If consensus cannot be reached in the WTO, the United States and Europe could negotiate regional trade agreements and undermine the multilateral WTO. The tensions could also delay Russia's bid to join the WTO and seriously damage the health of a very fragile world economy.

\subsection{Value Of The Dollar}

The US has been plagued by slow economic growth and a trade imbalance. The Federal Reserve has lowered interest rates to levels not seen in decades with limited effect. Board of Governors Chairman Alan Greenspan, during his recent report to the US Congress, stated that the risk of deflation is higher than that of inflation. He acknowledged though that he thought the probability of deflation is rather low.

John Snow, the US Treasury Secretary, made headlines with his response to questions on the recent drop in the value of the dollar. He commented that a weaker dollar is good for American exports (and the worrisome trade imbalance). Whether this was a casual statement or an intention to signal the market of a US policy change, market participants reacted and the value of dollar dropped even further. The dollar has fallen $21 \%$ against the euro in the past year. (The Economist, May 24, 2003, p.31)

The Bush administration appears to be moving away from the policy of strong support of the dollar that was a hallmark of the administration of President Bill Clinton. President Bush, facing reelection in 2004, appears to have learned from the reelection loss of his father in 1992. To quote the Clinton campaign team, "it's the economy, stupid." The President is turning his focus towards the economy. With the US economy facing the threat of deflation, and with a current interest rates low, the FED has very little room to maneuver. However, the decline in the value of the dollar is tantamount to a decrease in the interest rates. This may be good for the US economy, but 
with the German economy facing possible deflation and the French economy stagnating, the declining dollar will hurt their exports. This has added another dimension to the political tension.

\section{Security Implications}

Terrorism and uncertainty have increased the costs of doing business for multi-national corporations. They must now provide more security to plants, fleets, personnel, etc. The threat of more attacks could disrupt the supply chains. The risks cannot be eliminated but with the cooperation of the multilateral community, they can be minimized. Below are some of the recent actions with security implications for the global community.

\subsection{Redundancy Or support?}

In Brussels, Europeans are discussing the establishment of their own military force. The original intent of the force was to share the security burden with the US. However, some European leaders have expanded the discussion to include the possibility of a EU security force that could challenge the US force in size and sophistication. The chair of the European Commission has said that one of the EU's chief goals is to create "a superpower on the European continent that stands equal to the US." (Business Week, May 5, 2003)

The US has questioned this action and said that it will reduce the importance of the NATO alliance by creating a competing security force. The US prefers to work through the existing security framework and expand its importance by increasing the membership. Mr. Chirac has told Mr. Bush that he will approve a NATO peacekeeping presence in Iraq and would be willing to place it under American control. France has agreed to contribute troops to the NATO presence in Iraq. Given that the creation of a stable Iraqi government may take some time, NATO can provide an important role of support to US troops. Mr. Bush may not want a French role in Iraq, but he seems open to NATO providing additional security. (Business W eek, May 15, 2003) The Bush administration continues to build its ties with the "new Europeans" and has asked Poland to play a prominent peacekeeping role in Iraq.

\subsection{US Troops Move East}

The US continues to plan a major shift of US troops stationed in Europe from Germany to new or aspiring NATO members in Eastern Europe. The official rational is the need for smaller, more mobile units in locales closer the areas of potential conflict in the Middle East. However, observers state the action is a direct result of the German government's lack of support for US action in Iraq, and the anti-American remarks in the reelection campaign of German Chancellor Gerhard Schroeder.

Germany is currently home to 80 percent of the 112,000 US troops stationed in Europe. The US Army announced that it would withdraw 3,700 troops from five bases in Hesse in 2007 and 2008. Additionally, five thousand dependents will be leaving the area. Hesse is also home to the 16,500 members of the Army's $1^{\text {st }}$ Armored Division who are currently deployed in Iraq. After their peacekeeping duties, they are not expected to return to Germany.

The closing of bases will mean the direct loss of 230 German jobs and will likely inflict deeper economic harm on the businesses in the surrounding area that depend on US patronage. This loss will occur as Germany faces little or no economic growth. German diplomats have been dispatched to Washington to try to mend fences, but so far with little success. (Los Angeles Times, May 9, 2003, p. 7) 


\section{Conclusion}

Given the globally integrated world that exists today, both sides know that they need to mend the differences. Their economies are so intertwined that they have to stave off a potential breakdown of the economic relationship. This paper highlights some of the political, economic, and security implications of the current divisions. But, we contend that pragmatism will triumph over geo-politics. Both sides will come to their senses and will try to make it work.

The victory in Iraq has provided the US with an opportunity to expand its influence in the region, promote democratic reforms, and revive the Mideast peace process. To secure peace in the region and provide homeland security, the cooperation of European allies is needed. The job cannot be done alone without great sacrifices of US economy. With the budget back in the red and a moribund economy, US should welcome a multilateral approach to a new world order.

For most of the EU members, there is no future in a prolonged confrontation with the US. The European Union is the ultimate outcome of the diplomatic success worked on by the member nations. Thus, mending of the relationship with the US will avoid the shelving of the ideal of a united European foreign policy.

The mending process began with the G-8 Meeting in Evian, France in June 2003. President Bush flew to Europe and met individually with Presidents Chirac and Putin. However, he made it clear that all is not forgiven. He visited countries in Eastern Europe that had supported the US war effort first, and stayed in Evian for only a short period before flying to Africa.

However, we believe that pragmatism will trump geopolitics. France, Germany and other European opponents of the war are likely to offer cash and assistance to rebuild Iraq. The war on terrorism is not yet over. The location or fate of both Saddam and bin Laden is still unknown. The world is still in danger and without the cooperation between US and Europe intelligence reports cannot be shared to the fullest. The need for one another is greater at this time than ever if the world is to achieve peace, secure a new world order, and put the global economy back on track. 
Notes 